\title{
Études/Inuit/Studies
}

BURN, Christopher (ed.), 2012 Herschel Island Qikiqtaryuk - A

Natural and Cultural History of Yukon's Arctic Island, Calgary, University of Calgary Press, 242 pages.

\section{Charles Arnold}

Volume 36, numéro 1, 2012

URI : https://id.erudit.org/iderudit/1015960ar

DOI : https://doi.org/10.7202/1015960ar

Aller au sommaire du numéro

\section{Éditeur(s)}

Association Inuksiutiit Katimajiit Inc.

Centre interuniversitaire d'études et de recherches autochtones (CIÉRA)

\section{ISSN}

0701-1008 (imprimé)

1708-5268 (numérique)

Découvrir la revue

Citer ce compte rendu

Arnold, C. (2012). Compte rendu de [BURN, Christopher (ed.), 2012 Herschel Island Qikiqtaryuk - A Natural and Cultural History of Yukon's Arctic Island, Calgary, University of Calgary Press, 242 pages.] Études/Inuit/Studies, 36(1),

207-208. https://doi.org/10.7202/1015960ar services d'Érudit (y compris la reproduction) est assujettie à sa politique d'utilisation que vous pouvez consulter en ligne.

https://apropos.erudit.org/fr/usagers/politique-dutilisation/ 


\title{
Recensions / Book Reviews
}

\author{
BURN, Christopher (ed.)
}

2012 Herschel Island Qikiqtaryuk - A Natural and Cultural History of Yukon's Arctic Island, Calgary, University of Calgary Press, 242 pages.

When viewed on a map of the Arctic, Herschel Island looks remarkably insignificant. Measuring only about $200 \mathrm{~km}^{2}$, this small island off the north coast of Yukon nonetheless is a microcosm of the environment and history of the western Canadian Arctic. It was a stage for the meeting of two worlds, and more specifically between the Qikiqtaryukmiut who lived on the island that they had known as Qikiqtaryuk since "time immemorial" and Europeans who, seeking whales, furs, souls, and sovereign ownership, came to the island that John Franklin had named in 1826 after a fellow countryman, John Herschel. Herschel Island is also emblematic of changes that are rapidly reshaping the northern environment.

Herschel Island Qikiqtaryuk - A natural and cultural history of Yukon's Arctic island, brings together contributions from 43 authors and co-authors under the editorship of Christopher R. Burns, a Professor of Geography at Carleton University. The expertise of the contributing authors spans a wide range of disciplines and is communicated to the reader in succinct yet informative chapters presented in six thematic sections.

The "Introduction" situates Herschel Island in time and space, provides information on John Herschel, and discusses Inuvialuit place names for features on the island and the nearby mainland. "Land and Water" covers the geography, geological history, and geology of the island, the climate, and the characteristics of the ocean, including the sea ice. A subtext to the chapters in this section is that Herschel Island and surrounding areas constitute a highly dynamic physical environment, with ongoing changes that are influenced by global warming. "Flora and Fauna" covers the biota (with the exception of humans) on the island and in the surrounding waters, and reveals the remarkable diversity of this Low Arctic ecosystem.

"People and Culture" brings together information from archaeology, oral history, archival images, and written documents to reveal the rich human history of the island, starting with the earliest evidence of ancestral Inuvialuit some 800 years ago, their cultural development over time into the Qikiqtaryukmiut (one of several related Inuvialuit regional groups), and the arrival of the aforementioned outsiders: whalers, missionaries, traders, police, scientists, and explorers. Weakened by diseases, Inuvialuit found it hard to resist the onslaught of new people and the things they brought with them, including material goods, belief systems, a cash economy, foreign laws, and control over many aspects of their lives by a distant government. 
It is a testament to the remarkable resiliency of the Inuvialuit that they survived those turbulent times, gathered strength and, in 1984, signed the first comprehensive land claim agreement in Canada north of the 60th parallel, the Inuvialuit Final Agreement (IFA). It was under the provisions of the IFA that the island was established as Herschel Island Territorial Park in 1987 in order to recognise its unique natural and cultural heritage.

The section on "Conservation and Governance" discusses the co-management regime whereby the Inuvialuit and the governments of Canada and Yukon work together to manage the park. This section also provides additional information on the status of historical buildings that are an important component of the park, and about ongoing research and monitoring activities that are intended to alert responsible agencies to natural and human-induced changes that could threaten the environmental and cultural resources that make Herschel Island one of the Arctic's special places.

This well-written and informative book strikes a nice balance between specialist knowledge and general information. The design is attractive, and the book is richly illustrated with photographs, maps, tables, and charts that complement and enhance the text. Brief biographies of the authors with photographs personalise their contributions. A three-column format and highlighted subtitles make it easy to find information. I had the good fortune of recently visiting Herschel Island with a copy of this book in my backpack, and can attest that it served as a superb reference when encountering the marvels and mysteries of the island. As its title suggests, it also stands on its own as a comprehensive natural and cultural history of Herschel Island/Qikiqtaryuk, whose significance cannot be measured by size alone.

\author{
Charles Arnold \\ Department of Archaeology \\ University of Calgary \\ mailing address: 6160 Aldergrove Drive \\ Courtenay, British Columbia V9J 1V7, Canada \\ arnold.charles199@gmail.com
}

DRAPEAU, Lynn (dir.)

2011 Les langues autochtones du Québec: un patrimoine en danger, Québec, Les Presses de l’Université du Québec, 222 pages.

Lynn Drapeau, dans l'avant-propos de ce volume, suggère que le présent recueil constitue un complément à l'ouvrage Les langues autochtones au Québec publié, il y a 20 ans, sous la direction de Jacques Maurais (1992). Il était en effet grand temps d'offrir un portrait contemporain des efforts pour préserver les langues autochtones au Québec. Cet ouvrage est constitué d'actes d'un colloque portant le même titre et tenu à l'Université du Québec à Montréal en décembre 2010. 